\title{
Kiedy naprawdę urodził się Leśmian. $O$ metryce i innych nieznanych dokumentach
}

Dorota Samborska-Kukuć 


\section{Kiedy naprawdę urodził się Leśmian. O metryce i innych nieznanych dokumentach}

Dorota Samborska-Kukuć

TEKSTY DRUGIE 2017, NR 4, S. 303-317

DOI: $10.18318 /$ td.2017.4.18

Dyć może uda się kiedyś odnaleźć metrykę urodzeD nia Leśmiana w aktach stanu cywilnego (jakiego urzędu?), jeśli w ogóle została sporządzona"1 - pisze Jacek Trznadel w wydanym niedawno Kalendarium Leśmianowskim. Metryka została sporządzona i udało się ją odnaleźć. A oprócz niej - kilkanaście jeszcze innych dokumentów urzędowych, z których dało się wyczytać nieznane szczegóły dotyczące poety i jego rodziny. Nowe aliaże i kombinacje uformowane z tych komponentów pozwalają na uzupełnienie i sprostowanie niektórych dotychczasowych ustaleń leśmianologów i umożliwiają - jako wskazówki - nowe poszukiwania. Z kłopotami związanymi z datą urodzenia Bolesława Leśmiana borykano się od początku, niejako z winy samego poety, który błędnie datował swoje przyjście na świat, wskazując na rok 1878. Na steli nagrobkowej poety data jeszcze inna - rok 1879 - podana przez jego stryjecznego kuzyna,

1 J. Trznadel Kalendarium Leśmianowskie. Życie i twórczość w układzie chronologicznym, PIW, Warszawa 2016, s. 18.
Dorota Samborska-

-Kukuć - dr hab., prof. UŁ, historyczka literatury, biografistka, zatrudniona w Zakładzie Literatury Pozytywizmu i Młodej Polski Uniwersytetu Łódzkiego. Opublikowała m.in. monografie pisarzy polsko-białoruskich i polsko-inflanckich (Jan Onoszko, Kazimierz Bujnicki, Ludwika Plater) oraz Od Puttkamerów do Konopnickich. Rewizje i rekonstrukcje biograficzne a także ponad 100 artykułów naukowych. Kontakt: ddsk@wp.pl

\section{http://rcin.org.pl}


Jana Lesmana (Brzechwę) ${ }^{2}$. Dziś biografowie dysponują tylko aktem chrztu poety z roku 1887, niejako wtórnym, bowiem jest to świadectwo konwersji, i to zbiorowej, przeprowadzonej przez ojca, Józefa Lesmana, który na przełomie 1886/1887 wraz z dwoma małoletnimi synami: Bolesławem i Kazimierzem, przeszedł na katolicyzm. Akt znajdujący się w księgach parafialnych św. Jana w Warszawie bardzo łatwo znaleźć, księgi te bowiem są opatrzone indeksami, choć jak twierdzi Piotr Łopuszański, długo aktu tego szukał. Nie ma potrzeby przytaczać tutaj dyskusji, jaka toczyła się na temat narodzin poety, omówionej wyczerpująco przez Jarosława Marka Rymkiewicza, niemniej dziwi to, że badacze, zamiast spekulować, nie podjęli podstawowych kwerend w dokumentacji gmin żydowskich, wiedząc przecież o pochodzeniu Leśmiana. Jako historyk literatury, biograf i genealog nader często spotykam takie zaniedbania, mające skutki w piętrzących się supozycjach, nierzadko wymagających o wiele więcej myślowego zaangażowania niż typowanie konkretnych archiwaliów, których przeszukiwanie zajmuje wprawdzie niemało czasu, ale rezultat jest przeważnie gwarantowany. Jest nim zdobycie wiedzy o faktach, uprawniających do stawiania dalszych kroków ${ }^{4}$. Hipotezy oparte na chybotliwym gruncie, tj. bez weryfikowalnych świadectw, skazane są przeważnie na tymczasowość, budowane na podstawie wyobrażenia lub prawdopodobieństwa, przeważnie wprowadzają w błąd.

2 Zawirowania wokół daty urodzenia Leśmiana omawia J.M. Rymkiewicz Leśmian. Encyklopedia, Wydawnictwo Sic! Warszawa 2001, s. 55-59. Tu także wybiórcza bibliografia tematyczna.

3 P. Łopuszański Bolesław Leśmian. Marzyciel nad przepaściq, Twój Styl, Warszawa 2006, s. 56-57. Z indeksacją metryk w parafiach katolickich na ogół nie ma problemu, bywa, że w okresie popowstaniowym, a więc w czasie obligatoryjnego sporządzania zapisów i skorowidzów w języku rosyjskim, czyli urzędowym, księża bojkotowali nakaz i jak najdłużej dokonywali notacji w języku polskim. Metryki w parafiach św. Jana, podobnie i św. Krzyża, i św. Andrzeja w Warszawie należą do tych starannie opisywanych.

W obszernych biografiach (w dużej mierze repetycjach) oraz przyczynkach życiorysowych pióra Piotra Łopuszańskiego (cytowana już praca Bolesław Leśmian. Marzyciel nad przepaściq oraz Leśmian, Wrocław 2000, Zofia i Bolesław Leśmianowie, Wydawnictwo Literackie, Kraków 2005, Z rodu księgarzy - warszawskie korzenie Bolesława Leśmiana, "Pamiętnik Literacki” 2003 z. 3) można znaleźć wiele informacji genealogicznych, ale nie są one poparte oryginalnymi dokumentami, to przytoczenia z cudzych prac (nawet z subiektywnych wspomnień rodzinnych!), a więc świadectwa wtórne, rodzące wątpliwości co do ich rzetelności. Inna rzecz, że biografie te mają charakter popularnonaukowy, trudno więc wnosić o to pretensje. Toteż genealogia Sunderlandów i Lesmanów wymaga weryfikacji i triangulacji poprzedzonych gruntownymi kwerendami archiwalnymi oraz oddzielenia wiedzy pierwotnej od zaciemniających obraz domysłów i familijnych klechd.

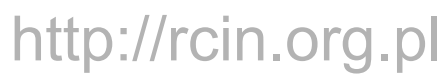


Oryginalny akt urodzin Leśmiana znajduje się - jak nietrudno było przewidzieć - w dokumentacji Urzędu Stanu Cywilnego Wyznań Niechrześcijańskich (cyrkułu X) pod numerem 27; sporządzony w języku rosyjskim jest dość staranny i czytelny. Czytamy w nim:

Состоялось в городе Варшава в Канцелярии Чиновника Гражданского Состояния Нехристиянского Исповядания Десятого Новосвятского Участия Февраля двадцать второго / Марта шестого / дня тысяча восемьсот семдесят седьмого года в десять часов утра, Явился на место затрудненного отца Шимон Флямберг пятидесяти девяти лет частный писец, под номером две тысячи четыреста двадцать пятым проживающий, в присутствии свидетелей Феликса Сосновского сорока лет под номером две тысячи семсот семдесят четвертым и Александра Коммпони, сорока лет, под номером тысяча двести третьим обоих частных официалистов в Варшаве проживающих - и предъявил нам младенца мужского пола, объявляя что он родился в Варшаве под номеров тысяча пятьсот шестьдесят четыре тым а Января десятого / двадцать второго / дня сего года в три часа по полудню от Осипа Лессмана двадцати девяти лет, редактора журнала «Пржирода и Пржемысл» и жены его, Эммы урожденной Сундерлянд, двадцати двух лет. Младенцу этому наричено имя Болеслав. Акт сий являющимся прочтенный Нами и ими подписан.

[Działo się w mieście Warszawie w Kancelarii Urzędnika Cywilnego Wyznań Niechrześcijańskich Cyrkułu X, Nowoświeckiego dnia 22 lutego/6 marca 1877 roku o 10 godzinie z rana, zgłosił się w zastępstwie za ojca [dziecka] zamieszkały pod numerem $2425^{5}$ [tj. na ul. Nowolipie 28] pięćdziesięciodziewięcioletni Szymon Flamberg, pisarz, czterdziestoletni Feliks Sosnowski zamieszkały pod numerem 1774 [tj. Świętojerska 2o] oraz czterdziestoletni Aleksander Kampioni, zamieszkały pod numerem 1203 [tj. Pańska 17], obu prywatnych oficjalistów zamieszkałych w Warszawie i okazał nam niemowlę płci męskiej, ogłaszając, że urodziło się w Warszawie pod nr 1564a [Chmielna 17] w dzień 10 stycznia/22 stycznia bieżącego roku o trzeciej godzinie po południu, z dwudziestodziewięcioletniego

5 Jest to numer hipoteczny. Numer policyjny, tj. konwencjonalny adres, ustalam na podstawie Taryfy domów miasta Warszawy z 1873 roku.

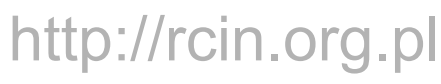


Józefa Lessmana, redaktora czasopisma „Przyroda i Przemysł” i jego żony, dwudziestodwuletniej Emmy, z domu Sunderland. Dziecięciu temu nadano imię Bolesław. Akt ten został odczytany i podpisany ${ }^{6}$.]

Odnaleziona metryka potwierdza więc datę narodzin widniejącą w akcie konwersji. To po pierwsze. Po drugie - wskazuje na nieznane dotąd miejsce narodzin - ul. Chmielna 17. Po trzecie, dowodzi jednego tylko imienia - Bolesław. Po czwarte - wnosi nowe informacje o ojcu (jako redaktorze pisma) i modyfikuje wiek matki. Rozważmy zatem te informacje i osadźmy w kontekstach - znanych lub rozpoznanych.

Można już teraz zatem z całą pewnością, opierając się na źródle prymarnym ${ }^{7}$, określić czas i miejsce przyjścia poety na świat. Stało się to w poniedziałkowe popołudnie 10/22 stycznia $1877 \mathrm{r.}^{8}$ przy ulicy Chmielnej 17 (róg z Bracką 22), w narożnej, dwupiętrowej kamienicy wzniesionej w latach 50. XIX wieku, należącej wówczas do księcia Jana Tadeusza Lubomirskiego (1826-1908), aktywnego działacza w warszawskim Towarzystwie Dobroczynności9.

Imię nadane aktem urodzenia brzmiało: Bolesław. Fakt ten kwestionuje słowa córki poety, Marii Ludwiki Mazurowej, twierdzącej, że ojciec miał na pierwsze imię Stanisław, bo obchodził imieniny 8 maja ${ }^{10}$. Imię Stanisław zostało mu nadane dopiero na chrzcie. Przy okazji dygresyjna uwaga na temat przekazów rodzinnych: klechdy reprezentujące zbiorową pamięć rodzinną w wersji oralnej mają strukturę osmotyczną, przenikają do niej składniki o rozmaitej proweniencji, na ogół subiektywne intencje i wyobrażenia dowodzące bezwiednej zdolności fantazjotwórczej członków familii

6 USC Warszawa/wyznanie mojżeszowe, cyrkułX, w: APW [Archiwum Państwowe w Warszawie] sygn. 72/200/151, akt nr 27 z roku 1877, s. 448.

7 O "definitywnym rozstrzygnięciu" daty urodzin donosił już A. Kędziora Akta osobowe Bolesława Leśmiana w zbiorach Archiwum Państwowego w Zamościu, „Archiwariusz Zamojski” 2005, s. 9), choć opierał się na źródle wtórnym, tj. odpisie świadectwa urodzenia i chrztu Leśmiana złożonym w aktach osobowych sądu zamojskiego.

8 Wedle informacji zawartej w numerze 15. "Gazety Warszawskiej” z dnia 10/22 stycznia 1877 roku (s. 1) temperatura powietrza wynosiła rano -4 , a po południu $-2^{\circ} \mathrm{C}$, słońce zaszło o 16.27 .

9 W czasie powstania 1944 roku kamienica uległa zniszczeniu; dziś jest odbudowana i podwyższona o piętro, zob. J. Zieliński Atlas Dawnej Architektury Ulic i Placów Warszawy, t. 1, Biblioteka Towarzystwa Opieki nad Zabytkami, Warszawa 1995, S. 205.

10 M.L. Mazurowa Podróże i praca twórcza Bolesława Leśmiana, w: Wspomnienia o Bolesławie Leśmianie, red. Z. Jastrzębski, Wydawnictwo Lubelskie, Lublin 1966, s. 73.

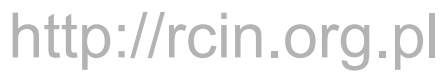


i ich skłonności do kontaminacji zasłyszanego z domniemanym. Toteż przy formowaniu życiorysów historie rodzinne zawsze należy traktować z dużą ostrożnością i dozą wątpliwości, nie należy ich w żadnym wypadku zrównywać z formami zweryfikowanymi w triangulacji. Wspomnienia Mazurowej są niemal modelowe dla tego typu praktyk, na nieścisłości jej historii zwraca uwagę - i słusznie - Trznadel ${ }^{11}$. Dodałabym jeszcze, że egzaltacja memuarystki i skłonność do mistycyzmu stawia pod znakiem zapytania wiarygodność jej przekazu, podobnie zresztą rzecz ma się z reminiscencjami Brzechwy ${ }^{12}$. Wracając do kwestii wiodącej - bredni w rodzaju: „Leśmian miał na imię Boruch”, co miało oznaczać „implantację” Żyda do polskiej kultury, nie warto nawet komentować13.

Akt zawiera - jak większość metryk żydowskich ${ }^{14}$ - cenną informację o zatrudnieniu ojca, dowiadujemy się więc, że Józef Lesman był redaktorem w czasopiśmie „Przyroda i Przemysł”. Ten nieznany dotąd fakt z życia ojca poety potwierdzony w impressum periodyku wzbogaca wiedzę o tym niepospolitym człowieku. Jako absolwent Wydziału Matematyczno-Fizycznego Szkoły Głównej interesował się wieloma dziedzinami wiedzy i popularyzował ją. Był więc nie tylko - jak twierdzą biografowie jego syna - urzędnikiem kolejowym ${ }^{15}$, ale także intelektualistą. „Przyroda i Przemysł. Tygodnik popularnonaukowy poświęcony rozpowszechnianiu nauk przyrodniczych i ich zastosowań do przemysłu" ukazywał się dziesięć lat (1872-1881) ${ }^{16}$. Początkowo jego redaktorem i wydawcą w jednej osobie był Karol Hertz (1843-1904), pod koniec drugiego, tj. 1873, roku ukazywania się pisma jego wydawcą został Seweryn Sunderland, a od wiosny roku następnego (nr 21 z 1874 roku) dołączył do niego Lesman jako redaktor. Pozostał nim do końca 1877 roku, a więc pracował w „Przyrodzie” prawie cztery lata. Niestety, z uwagi na anonimowość

11 J. Trznadel Kalendarium Leśmianowskie..., passim.

12 J. Brzechwa Niebieski wycieruch, w: Wspomnienia o Bolesławie Leśmianie, s. 79-105.

13 Kolportowanie takich nonsensów na internetowych stronach antysemickich nie może być traktowane poważnie. Leśmian podzielił tam los Leo Belmonta (Leopolda Blumentala), a nawet Fryderyka Chopina. Zjawisko nadaje się raczej do badań psychopatologii, nie zaś biografistyki.

14 Ale także chrześcijańskich, podawanie informacji o zatrudnieniu ojca zależy od parafii oraz okresu sporządzania metryk.

Zob. L. Maligranda (Lulea) Karol Hertz (1843-1904) - absolwent Szkoły Głównej Warszawskiej, „Antiquitates Mathematicae” 2009 (rocz. 3), s. 65-87. „Przyroda i Przemysł” przekształciła się później w czasopismo „Wszechświat”.

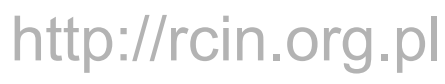


zamieszczanych w czasopiśmie artykułów, nie da się ustalić, które z nich były autorstwa Lesmana. Hertz i Lesman mogli znać się już z Warszawskiej Szkoły Rabinów, którą do początków lat 50. kierował Antoni Eisenbaum, dziadek Józefa, a której obaj byli wychowankami, razem studiowali także w Szkole Głównej na Wydziale Matematyczno-Fizycznym.

Zgodnie z omawianą metryką matka poety, Emma Sunderlandówna miała w roku jego urodzenia lat dwadzieścia dwa, ojciec zaś dwadzieścia dziewięć. O ile zgadza się wiek ojca (zgodnie z aktem chrztu urodził się 4/16 grudnia 1847 r.), wiek matki, która miała się urodzić 11 marca 1852 roku (taki zapis jest na macewie jej nagrobka postawionego przez braci) został poważnie zaniżony i wskazywałby na rok 1855 lub 1854 .

Niewiele da się powiedzieć o świadkach urodzenia Leśmiana. O ile Aleksander Kampioni i Szymon Flamberg, byli urzędnikami zapisującymi zgłoszone urodzenia żydowskich dzieci, o tyle Feliks Sosnowski mógł być w jakiś sposób z Lesmanami związany; niestety nie udało się ustalić tych ewentualnych związków, a tym samym być może bliższego otoczenia rodziców przyszłego poety".

Drugim istotnym dokumentem jest znajdujący się w aktach kancelarii gminy żydowskiej cyrkułu VII, właściwego miejscu zamieszkania przyszłej matki poety (a także i wówczas ojca), Emmy Sunderlandówny, akt małżeństwa jego rodziców ${ }^{\mathbf{1 8}}$. Zawiera on także wzmiankę o tym, że została zawarta umowa

17 Drobiazgiem, aczkolwiek przez biografów pominiętym, są rodzice chrzestni Józefa i jego dwu synów: Maurycy i Eleonora Nowiccy, wpisani we wszystkie trzy metryki chrztu (nry aktów 28, 29, 30 z roku 1887). Podstawą informacyjną przy identyfikacji tych osób jest akt ich zaślubin z roku 1849 (USC Warszawa/parafia rzymskokatolicka św. Krzyża, w: APW, sygn. 158, akt nr 206 z roku 1849, s. 354), z którego wynika, że szlachcic Maurycy Nowicki urodzony w 1820 roku w Warszawie, syn Ignacego i Tekli z Mereckich, mieszkał na Tamce, jego żona zaś, Eleonora Marianna, urodzona w 1826 roku, również w Warszawie, była córką Idziego i Marianny z Kossowskich Sikorskich, zamieszkała przy Nowym Świecie. Byli to więc w roku 1877 ludzie już starsi, należeli do pokolenia ojca Lesmana, księgarza warszawskiego i nauczyciela w szkole rabinów - Bernarda. Niewykluczone, że byli to znajomi rodziny, ale również mogli być przygodni; wiele jest przypadków, że katolickie małżeństwa, rodzeństwa etc. świadkują wielu ceremoniom chrztów neofitów. 1876, s. 682.

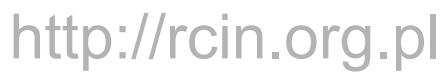


małżeńska (ketuba), spisana osobno i podpisana u rejenta Józefata Fiedeckiego w Warszawie.

Co możemy z aktu tego wyczytać? Data zaślubin - 3/17 marca 1876 roku dowodzi, że Bolesław był najstarszym dzieckiem Lesmanów, przed Kazimierzem Antonim, urodzonym 30 listopada/12 grudnia 1877 roku $^{19}$ (zmarłym 15/28 marca $1907 \mathrm{roku}^{20}$ ) i, jeśli zawierzyć wspomnieniom córki poety, przed trzecim synem, nieznanym z imienia, urodzonym po roku 1877, ale zmarłym z pewnością przed rokiem 1887 (nie przeszedł konwersji) oraz Aleksandrą (o której będzie jeszcze mowa), urodzoną prawdopodobnie w roku 1887, zmarłą w 1921 roku.

Z aktu ślubu Lesmanów wynika, że Józef był wówczas sąsiadem Sunderlandów, mieszkał w pobliskiej kamienicy na Orlej, dokąd przeniósł się zapewne z Elektoralnej 2021. Jeszcze wcześniej, w latach 50., rodzina Bernarda i Reginy z Eisenbaumów ${ }^{22}$ mieszkała na ulicy Nalewki $41^{23}$, gdzie prawdopodobnie urodził się Józef"

19 USC Warszawa/wyznanie mojżeszowe, cyrkuł VII, w: APW, sygn. 72/200/113, akt nr 96 z roku 1878, s. 79. O ile Bolesław był jednoimienny, jego młodszy brat od początku miał dwa imiona, taki jest zapis w akcie urodzenia z 1878 roku.

20 USC Warszawa/parafia rzymskokatolicka św. Aleksandra, w: APW, sygn. 162, akt nr 227 z roku 1907, s. 39.

21 Przewodnik warszawski informacyjno-adresowy na rok 1870, ułożył W. Dzierżanowski, Drukarnia S. Orgelbranda, Warszawa 1870, s. 210.

22 Regina Eisenbaum, córka Antoniego (dyrektora Szkoły Rabinów w Warszawie, pisarza, działacza proasymilacyjnego) i Fryderyki z Goldsteinów urodziła się 11 listopada 1824 roku w Warszawie (USC Warszawa/wyznanie mojżeszowe, cyrkuł I, II, VI, sygn. 180,akt 233/703 z roku 1828, s. 117. W tymże roku Antoni Eisenbaum zgłaszał narodziny aż sześciorga swoich dzieci, urodzonych między 1817 a 1828 r. Oprócz aktu Reginy, znajdują się metryki: Julianny, Michała, Ludwika, Filipiny, Wiktora (kolejne akty od 230-235).

23 Wynika to z odnalezionego aktu urodzenia Antoniego Lesmana urodzonego 7 listopada 1852 roku (USC Warszawa/wyznanie mojżeszowe, cyrkuł VI sygn. 180, akt nr 464 z roku 1852, s. 79), akt konwersji: USC/parafia św. Andrzeja, sygn. 159, akt nr 371 z roku 1882. W latach 8o. Antoni z żoną Ewą z Bergerów mieszkał na Orlej, zdaje się, że w tej samej kamienicy, w której jego brat przed ślubem.

24 Spekulacje Łopuszańskiego (Bolesław Leśmian. Marzyciel nad przepaściq, s. 55-56) wsparte nieujawnionym zresztą w tekście Skorowidzem mieszkańców Warszawy z 1854 roku zupełnie się zatem nie potwierdzają. Ów Izaak to nie Józef, który nigdy nie był subiektem. Na wątłej przesłance buduje biograf sporą opowieść o rzekomym miejscu przyjścia na świat poety. Jest to przykład wyciągania daleko idących wniosków nieopartych na jakiejkolwiek pewnej informacji. Drugim, nagminnym lapsusem Łopuszańskiego jest założenie, że imiona nadawane dzieciom asymilujących się lub zasymilowanych rodzin żydowskich miały postać tradycyjną

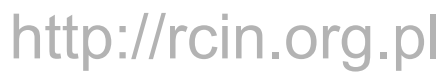


Rodziny Lesmanów i Sunderlandów znały się dużo wcześniej, łączyła je osoba Eisenbauma ${ }^{25}$. Nie dziwi więc, że Józef Lesman i Seweryn Sunderland współpracowali ze sobą w czasopiśmie „Przyroda i Przemysł”. Śluby zawierane w tych rodzinach dowodzą zażyłości. W dniu 11/23 lutego 1876 roku brat Emmy Sunderland, Seweryn ${ }^{26}$, poślubił siostrę Józefa Lesmana, Gustawę ${ }^{27}$, a w trzy tygodnie później, tj. 5/17 marca, pobrali się rodzice przyszłego poety.

Kolejną interesującą kwestią jest to, że w akcie ślubu Emma Sunderland widnieje i podpisuje się imieniem Ewa, odziedziczonym zapewne po siostrze ojca, Ewie z Sunderlandów Wohlowej ${ }^{28}$. Aktu urodzenia Emmy (Ewy) nigdzie nie udało się odnaleźć, toteż trudno wnioskować, czy takie zostało jej nadane przy urodzeniu ${ }^{29}$. Tak czy inaczej później, w aktach urodzenia synów i córki wpisywana jest jako Emma. Takie imię jest również na macewie.

„Panieńskie nazwisko babki poety (od strony matki) pozostanie więc zapewne nieustalone" - pisze Rymkiewicz. Odnalezienie metryk paradoksalnie wprowadza zamieszanie. W akcie małżeństwa Emmy i Józefa nazwisko to brzmi: Wolfsdorf, imię - Maria. I rzecz można byłoby zakończyć, tymczasem... mam w ręku jeszcze dwa akty dotyczące Sunderlanów, synów Rudolfa: zaślubin Seweryna Salomona z Lesmanówną i urodzenia Maksymiliana $^{30}$. W każdym z nich jest wpisane inne nazwisko matki: w akcie Seweryna - Maria Wohl, Maksymiliana - Maria Salomon. To, razem z aktem ślubu Emmy, gdzie występuje Maria Wolfsdorf - aż trzy Marie. Czy Rudolf miał więc trzy żony? Tożsamość imienia raczej wyklucza taką możliwość.

i że dopiero aktem chrztu były one słowiańskie lub inne, używane przez chrześcijan. Nic bardziej błędnego - w aktach gmin żydowskich niemalże wszystkie rodziny zasymilowane nadają od razu imiona, które uznane są powszechnie za polskie (lub niepolskie), inaczej oczywiście rzecz się ma z rodzinami ortodoksyjnymi lub nieasymilującymi się.

Kwestie powinowactw i pokrewieństw Eisenbauma z Lesmanami oraz Sunderlandami omawiam w osobnym artykule: Antoni Eisenbaum - protoplasta poetów, artystów, intelektualistów. Seweryn Sunderland, jak wynika z ksiąg adresowych Warszawy różnych lat, był adwokatem przysięgłym Okręgu Sądowego Warszawskiego.

Gustawa Lesmanówna urodziła się 3 października 1854 roku. USC Warszawa/wyznanie mojżeszowe, cyrkuł VII, w: APW, sygn. 180, akt 166 z roku 1855, s. 28. Akt zaślubin: USC Warszawa/ wyznanie mojżeszowe, cyrkuł VII, w: APW, sygn. 72/200/111, akt nr 9 z roku 1876, s. 339. Ewa Sunderlandówna wyszła za mąż za szwagra swojego brata, nieznanego z imienia Wohla. Niektórzy biografowie wspominają o obocznym wobec Emmy imieniu Estera, ale w żadnym dokumencie nie znalazłam na to potwierdzenia.

USC Warszawa/ wyznanie mojżeszowe, cyrkuł VII, w: APW, sygn. 180, akt 352 z roku 1847.

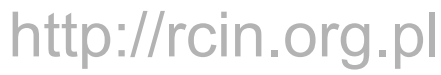


Co więcej, ze źródeł wiemy (choć nie na pewno, ponieważ do aktu zgonu nie dotarłam), że Maria(nna) z Wohlów Sunderlandowa zmarła w 1888 roku $^{31}$, a więc już po śmierci Rudolfa (zmarłego prawdopodobnie w 1880 roku) - czy zatem ta sama kobieta była matką czworga jego dzieci? Raczej tak. Z dużą dozą prawdopodobieństwa można przyjąć, że matką Emmy (i pozostałych dzieci) była Maria z Wohlów Sunderlandowa, córka Salomona i Cyprianny z Eisenbaumów.

Teraz kilka uwag o adresach, również wyczytanych z metryk. J. Lesman był dość ruchliwy, często zmieniał miejsce zamieszkania. Ewolucja tych przemieszczeń jest - można by tak rzec - typowa dla rodzin asymilanckich. Najpierw Nalewki, potem Elektoralna, Orla, następnie - co wynika z zapisków w stopce „Przyrody” - Włodzimierska (dziś Czackiego), w końcu Chmielna. Jest prawdopodobne, że już latem 1877 roku Lesmanowie wyprowadzili się z Chmielnej, poza cyrkuł X, na ulicę Chłodną mieszczącą się w obrębie cyrkułu VII. Taki identyfikator adresowy widnieje bowiem w akcie urodzin Kazimierza spisanym w dniu 8/20 marca 1878 roku. Dokładny adres nie jest możliwy, bowiem nie podano oznaczenia literowego, a jedynie numer hipoteczny: 927. Wskazuje on kilka adresów: Chłodna 15-21, Żelazna 28, Krochmalna 32. Przyszły autor Łąki skończył więc pierwszy rok życia w którejś z kamienic mieszczących się w czworokącie ulic: Chłodnej, Krochmalnej, Żelaznej i Waliców. Po tej dacie Lesmanowie już nie pojawiają się w żadnej z dostępnych ksiąg metrykalnych. Nie jest zatem wykluczone, że opuścili Warszawę. Czy już wówczas wyjechali do Kijowa? Czy nastąpiło to przed pogrzebem ojca Józefa, zmarłego we wrześniu roku 1878 Bernarda Lesmana, czy po nim? ${ }^{32}$

$*$

Zarówno sam poeta, jak i jego córka piszą o Ukrainie jako o kraju jego dzieciństwa („Ta niepojęta zieloność to Ukraina, gdzie się wychowałem”33,

31 Jej grób (a także innych Sunderlandów) znajduje się na cmentarzu ewangelicko-reformowanym w Warszawie, zob. J. i E. Szulc Cmentarz Ewangelicko-Reformowany w Warszawie. Zmarli i ich rodziny, Warszawa 1989, s. 228. Istnieją rozbieżne na ten temat zdania. Wedle Rymkiewicza (Leśmian..., s. 165) Lesmanowie opuścili Warszawę "mniej więcej w roku 1879 ".

33 E. Boye Wywiad z B. Leśmianem, w: B. Leśmian Dzieła wszystkie, t. 2, Szkice literackie, Warszawa 2011, s. 547.

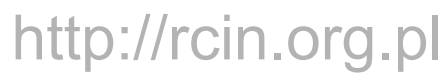


„Dzieciństwo ojca to bujna przyroda ukraińska" ${ }^{34}$ ). Jeśli połączyć to wspomnienie z ustaleniami Włodymyra Wasyłenki, które nie wiadomo dlaczego są podważane $e^{35}$, że po pierwsze: Józef Lesman już od 1 lutego 1879 roku był zatrudniony w Kijowie, a przyszły poeta rozpoczął naukę w kijowskim gimnazjum klasycznym w 1886 roku $^{36}$, dodać absencję Józefa Lesmana w księgach adresowych Warszawy oraz jeszcze jedną, nową informację wynotowaną z kijowskiego kalendarza adresowego (o czym niżej), można zaryzykować hipotezę, że w początkach lat 8o. Lesman (lub Lesmanowie) przebywali już w Kijowie. Józef musiał tam mieszkać z całą pewnością przed rokiem 1887, a zatem wcześniej niż dokonał konwersji, dowodem na to jest umieszczenie jego nazwiska w księdze adresowej guberni kijowskiej na rok 1887, zatem przygotowywanej co najmniej rok przed wydaniem (jest to publikacja podobna do np. „Kalendarza” Józefa Ungra). W publikacji tej Lesman zostaje wskazany jako członek Zarządu Związku Południowo-Zachodniej Kolei Żelaznej (pełni funkcję zarządcy finansami, zajmuje się kasą emerytalną) ${ }^{37}$. Tym samym niezgodności co do wykonywanej przez Lesmana pracy w Kijowie zostają zniesione i, jak się okazuje - najdokładniejsze w tym zakresie informacje posiadała nie córka poety, ale Jan Brzechwa ${ }^{\mathbf{3}}$.

Wobec tego zatrudnienia pewną sprzecznością jest identyfikacja zawodowa Lesmana zawarta w akcie jego chrztu z 1887 roku, gdzie został wpisany jako księgarz. Być może dysponował jakimś starym odpisem, w którym figurował jako księgarz właśnie, a może - i to wydaje się poważniejszym

M.L. Mazurowa Podróże i praca twórcza..., s. 46.

J. Trznadel, a za nim i inni biografowie uważają, że informacje Wasyłenki, pochodzące z kwerend archiwalnych w Kijowie, są nieprawdziwe. Powodem jest błędne założenie, że dopiero W 1887 roku (data konwersji i zgonu Lesmanowej) Bolesław wraz z rodziną (lub tylko z ojcem) wyjechał do Kijowa. Tok rozumowania badaczy jest tu zadziwiający. Dlaczego ów rok 1887 miałby być delimitacją? To typowe błędne założenia, które spotykam w wielu biografiach obarczonych sprzecznościami. Oparte są na ogół na imaginacjach biografa, jego „zdrowym rozsądku”, zasadzie prawdopodobieństwa, czerpaniu ze wspomnień rodzinnych (sic!), a dokumenty niepasujące do tych wyobrażeń są dezawuowane. Nic dziwnego, że przy takim rozumowaniu, trudno cokolwiek uporządkować.

W. Wasyłenko Bolesław Leśmian. I. Kijowskie lata leśnego miana, w: tegoż Ukraińskim tropem polskich pisarzy XIXiXX wieku, Wydawnictwo Fundacji Literackiej, Poznań 1996, s. 103-104.

37 „Сборник Сьъидъний по киеьской губерни и адресъ-календар на I887 год”, Киеb I887, s. I5. 
powodem - nie chciał ujawniać zamieszkania w Kijowie (w metryce wpisano by - jak to zawsze czyniono dla zatrudnionych przy kolei - pełną nazwę instytucji). Badacze zwrócili uwagę na to, że przejście Lesmana na katolicyzm wiązało się z jego zatrudnieniem na kolei, a ta strategiczna tkanka gospodarcza, podobnie jak aparat policyjny, była monitorowana pod kątem kadrowym. Został zatem przymuszony do okazania swej dotąd nieujawnionej polskości? Czy może zmianą wyznania chciał przypieczętować rozstanie z żoną, która nie chciała odejść od judaizmu (jej brat Seweryn już wcześniej zmienił je na protestantyzm)?

*

Wobec luk czy niejasności biograficznych wynikających z braku lub nieistnienia wiarygodnych źródeł, mogących je zapełnić, badacz jest skazany na hipotezy. Do takich białych plam należy właśnie okres dzieciństwa Leśmiana, wobec powyższych ustaleń (a także przeniknięcia jego poezji nie tylko realnym, ale i mentalnym pejzażem ukraińskim) można skłonić się ku podejrzeniu, że mieszkał i wychowywał się na Ukrainie od wczesnych lat dziecięcych. Czy z obydwojgiem rodziców, czy tylko z ojcem i bratem? Jeśli prawdziwa jest dość poetycka opowieść Mazurowej o trzecim, nieznanym z imienia synu Lesmanów („Nad biurkiem ojca wisiała fotografia młodszego braciszka mego ojca, zmarłego w Kijowie. Robiła wrażenie obrazu. [...] Mały, ciemnowłosy chłopczyk, uczesany na pazia, śpi w zbożu, zmorzony snem wiecznym. Obok niego porzucony słomkowy kapelusz. Nieludzki wysiłek mózgu spowodował szybką śmierć. Miał cztery lata. Mówił wierszem. Nie używał prozy. Był nad wiek rozwinięty. Kiedy umierał, ojciec był też niewiele od niego starszy"39), Lesmanowie powinni byli przebywać w Kijowie całą rodziną. Trudno informacje te zweryfikować, ponieważ z powodu ogromnych ubytków w warszawskich księgach metrykalnych wyznania mojżeszowego z lat 8o. niemożliwe jest ustalenie, czy ów trzeci syn urodził się i/lub zmarł w Warszawie. Należałoby więc dokonać kwerend w Centralnym Państwowym Archiwum Historycznym w Kijowie.

Skąpe informacje o drugim z kolei synu Lesmanów, Kazimierzu, udało się odrobinę wzbogacić. Wspomniany wyżej akt urodzenia potwierdził znaną już datę: 30 listopada/12 grudnia 1877 roku, a jednocześnie zaprzeczył, by imię Antoni zostało mu nadane aktem chrztu, od początku miał, w odróżnieniu od 
Bolesława, dwa imiona. W parafii św. Aleksandra w Warszawie odnalazłam akt zgonu Kazimierza, zmarł jako niespełna trzydziestoletni kawaler, 15/28 marca 1907 roku przy al. Szucha; w nieznanym dotąd, zawiadamiającym o pogrzebie nekrologu prasowym w „Kurierze Warszawskim” podano błędnie lat $28^{40}$. W obu źródłach Kazimierz nazywany jest „wychowankiem uniwersytetu kijowskiego".

Zagadką, w chwili obecnej raczej nierozwiązywalną, jest również sytuacja rodzinna poety, rzekoma separacja (rozwód) rodziców, a potem porwanie dzieci przez Lesmana, o czym pisze Jan Brzechwa. Te rewelacje nie zostały potwierdzone żadnym dokumentem ani nawet innym wspomnieniem rodzinnym $^{41}$. Niepokojące jednak jest to, że Mazurowa pisze: „Ojciec nie pamiętał swojej rodzonej matki. Umarła na suchoty"42, podkreślając zarazem jego niechęć do macochy, Heleny z Dobrowolskich, ale pokazuje jednocześnie Leśmiana w przestrzeniach do tej drugiej należących (kanikuły na ukraińskiej wsi, gdzie mieszkała rodzina Dobrowolskiej), wspomina o wierszyku ośmioletniego poety pisanym dla matki swojej macochy, przytacza słowa z listu Dobrowolskiej, że „dzieci psują zabawki”. A więc macocha znała je od wczesnych lat? Wygląda to trochę tak, jakby Emma Lesmanowa została z jakiegoś powodu wyeliminowana, wykluczona. Z powodu choroby? Jeśli tak, to tylko umysłowej, która mogła uniemożliwiać jej wychowanie dzieci, a jednocześnie stać się powodem unieważnienia małżeństwa. Umarła (czy rzeczywiście na gruźlicę? skąd to wiadomo? jeśli jedynym źródłem są wspomnienia jej wnuczki, można mieć co do przyczyny tej śmierci niejakie wątpliwości), jak stanowi zapis na macewie: 1 sierpnia 1887 roku $^{43}$, nie jest więc możliwe, by dziesięcioletni wówczas syn jej nie pamiętał. A jeśli rzeczywiście nie pamiętał, rozłączono go z matką we wczesnym dzieciństwie. Nie przeszła konwersji, jak mąż i synowie, umarła jako Żydówka i została pochowana na

Inna rzecz, że zapis na macewie nie musi być właściwy. Wielokrotnie spotykałam takie lapsusy: data dzienna poprawna, ale roczna - już nie.Co więcej, mogło nastąpić też odwrócenie daty dziennej i miesięcznej, a to wskazywałoby, że Emma Sunderlandowa umarła nie 1 sierpnia, ale 8 stycznia 1887 roku, tj. cztery dni przed przyjęciem chrztu przez jej męża i synów (sic!). Trudno jednak - wobec braku aktu jej zgonu o takiej ewentualności wyrokować, musi mieć ona status hipotezy. 
cmentarzu żydowskim przy Okopowej w Warszawie. Nagrobek postawili jej bracia, jak uwiadamia inskrypcja nagrobna. Nie mąż. A więc Emma i Józef Lesmanowie żyli osobno? Ona w Warszawie, on w Kijowie? Od kiedy Józef miałby zatem przy sobie synów? A jeśli prawdziwa jest opowieść o trzecim synu, gdzie się urodził i gdzie umarł? Jeśli w Kijowie, oznaczałoby to, że Lesmanowie mieszkali tam razem czas jakiś. Może to śmierć tego dziecka poróżniła małżonków? A może pojawienie się w życiu „pięknego Józefa” - jak nazywano Lesmana w Kijowie - innej kobiety? Sytuację gmatwają jeszcze bardziej narodziny Aleksandry, która miała przyjść na świat w roku śmierci matki, a została ochrzczona w rok później w Kijowie jako córka Józefa i Emmy z Sunderlandów ${ }^{44}$. Intrygującego przypuszczenia Trznadla, że nie była ona córką Emmy, ale Heleny, nie potwierdza dokument ${ }^{45}$. I cała spekulacja okazuje się niedowodliwa. Być może odnalezienie aktu zgonu Emmy Lesmanowej coś by podpowiedziało, nie ma go w warszawskich metrykach gmin niechrześcijańskich - mocno jednak niekompletnych.

Gdyby jednak odrzucić reminiscencje Brzechwy jako nieprawdziwe i uznać, że żadnej separacji i porwania dzieci nie było, a opowieść autora Pana Kleksa miała charakter niejako eskamotowania własnych przewin (opuszczenie żony Maryni Sunderland, co spotkało się z oburzeniem Leśmiana), pozostaje wciąż niejasna formuła wspomnień o matce jako bycie zastygłym w „pradawnej” przeszłości. Wskutek niemal zupełnej niepamięci poety o matce raczej mało prawdopodobne, by umarła w Kijowie, gdzie musiałaby mieszkać wraz z rodziną (co usprawiedliwiałoby jej nieobecność w Warszawie na przełomie 1886/1887, kiedy była brzemienna i być może też chora na gruźlicę), i tu urodzić najmłodsze dziecko - Aleksandrę. Dlaczego wobec tego nie spoczęłaby na cmentarzu kijowskim, a jej zwłoki przewożono by do Warszawy? Dzieciństwo Leśmiana okrywa gruba warstwa retuszu kryjąca rodzinne tajemnice.

44 Метрическая книга Киевского приходского римо-католического костела за 1888 год, Фонд 1268 Опись 1 Дело 34, Стр. 56об-57. Księga jest niedostępna, sporządzono z niej jedynie wypisy, w których czytamy krótką notkę: Лесман Александра - Жители г. Варшава Иосиф Лесман, Эмма Сундерлянт.

Teza ). Trznadla (Kalendarium Leśmianowskie..., s. 23), że Aleksandra nie mogła być córką Heleny, ponieważ wiersz Leśmiana Do siostry „przeczy temu wzruszającą prostotą”, jest mocno ryzykowna. Jeśliby Aleksandra byłą siostrą przyrodnią poety, nie musiano wtajemniczać w to pozostałych dzieci. Nie jest jednak wykluczone, że Aleksandra (a być może i ów zmarły w dzieciństwie braciszek) urodziła się w nieformalnym związku, a została zarejestrowana jako córka małżeństwa Lesmanów.

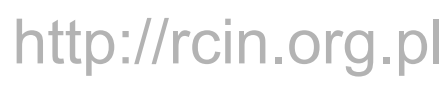


Leśmian, jak można wnosić z przejmującego wiersza Do siostry, troszczył się o młodszą o dziesięć lat Aleksandrę. Mazurowa pisze o niej: „Wołano na nią Ola. Była szczupła, wątła, subtelna, o dużych orzechowych oczach. Kijowscy przyjaciele wołali na nią «Wielka Ukraina». Anielskiej dobroci. Ojciec ją bardzo kochał. Ona też starała się pisać. [...] Umarła na suchoty w Otwocku. W domu przyjaciół Grabowskich"46. Aleksandra Lesmanówna zmarła latem, 20 czerwca 1921 roku, Otwocku ${ }^{47}$, po latach spoczął przy niej na Powązkach jej sławny brat.

Odnalezienie aktu urodzenia Bolesława Leśmiana definitywnie rozstrzyga zatem długie lata trwającą kwestię sporną. Ów „straszliwy zamęt”, jak spór ten nazywa Rymkiewicz ${ }^{48}$, może wreszcie ustać. Jednocześnie jednak odnalezione, dotąd nieznane dokumenty otwierają nowe tropy, intrygując zagadkami. Ale przecież o to w rekonstruowaniu biografii chodzi - o proces niejako emergencyjny; dzięki penetracji nowych źródeł i odkrywaniu świeżych materiałów wyłania się przecież coraz pełniejsza sylwetka poety. A że dzieje się to stopniowo? Coś przecież musi pozostać dla przyszłych pokoleń.

\footnotetext{
46 L.M. Mazurowa Podróże i praca twórcza..., s. 47

47 USC Otwock, akt nr 59 z roku 1921. Mazurowa pomyliła też nazwiska "przyjaciół”, byli nimi Góreccy, nie Grabowscy.

48 J.M. Rymkiewicz Leśmian..., s. 55.
} 


\section{Abstract}

\section{Dorota Samborska-Kukuć}

UNIVERSITYOFŁÓDŹ

When Was Leśmian Really Born: His Birth Certificate and Other Unknown Documents

We had no certainty about Bolesław Leśmian's date of birth until his birth certificate was found at the State Archive in Warsaw. The document corroborates the date listed on the poet's conversion certificate: he was born on Chmielna Street in Warsaw on the 10 January/22 January 1877 as the son of Józef Lesman and Emma, born Sunderland. Other documents that came to light thanks to Samborska-Kukućs archival research include his parents' marriage certificate and the birth and death certificates of his siblings, Kazimierz and Aleksandra. The data garnered from these sources allow us to fill some of the gaps in the poet's biography.

\section{Keywords}

Bolesław Leśmian, biography, Lesmanowie, Sunderland 